Wim H.J. van Bon

Robert Schreuder

University of Nijmegen, The Netherlands

\title{
Poor readers' decoding skills: Effects of training with limited exposure duration
}

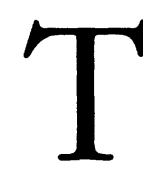
There is substantial evidence that poor readers' problems with developing adequate word identification skills are primarily associated with difficulties in phonological processing (Bradley \& Bryant, 1983; Wagner \& Torgesen, 1987). Compared with good readers, poor readers have weaker knowledge of grapheme-phoneme correspondences (Backman, Bruck, Hebert, \& Seidenberg, 1984; Bruck, 1988), are less inclined to employ a phonological decoding strategy (Barron, 1980; Mann, Liberman, \& Shankweiler, 1980), and are less proficient in applying a decoding strategy if task demands force them to do so (Henderson, 1985; Hogaboam \& Perfetti, 1978). Furthermore, there is evidence that children do not acquire word-specific orthographic knowledge unless they are capable of decoding the words rapidly and efficiently (Adams, 1990; Backman et al., 1984; Reitsma, 1983). In fact, a decoding deficiency seems to be the primary cause of reading problems (Perfetti, Beck, Bell, \& Hughes, 1987; Vellutino \& Scanlon, 1987). In the present study the efficacy of a training program for improving young poor readers' word decoding skills is investigated.

Remedial reading programs are often based upon the assumption that the time it takes to decode a word can be cut down substantially by repeated presentations. There is indeed substantial experimental evidence for positive effects of repetition on word identification time (e.g., Fiedorowicz, 1986; Hogaboam \& Perfetti, 1978; Reitsma, 1988a, 1988b; van Daal, Bakker, Reitsma, \& van der Leij, 1986). However, all studies failed to demonstrate a transfer effect from trained to untrained words, which reduces the value of this type of training considerably. The gains in identification time for practiced words are probably also overestimated in these studies. It is likely that repetition made children familiar with the words of the practice set. Instead of improving decoding, however, repetition may have stimulated the children to develop set-specific discrimination rules. If the same words are encountered in a different context, positive effects of prior experience may be limited or even nonexistent. This point of view is supported by a study of Fleisher, Jenkins, and Pany (1979). Poor readers were trained to fluently identify a set of words extracted from a text. After training they were tested on their comprehension of that text. They did no better than a matched group of poor readers who had received no training. Apparently, if poor readers learn to identify individual words as visual patterns and fail to recognize how letters function as symbols for sounds in pronunciations, no improvement in general word recognition skills as a result of practice may be expected (Adams, 1990; Ehri \& Wilce, 1983).

Studies of the effects of remedial reading programs providing children with ample practice in phonological decoding, however, have reported progress in generalized word identification skills. For example, Roth and Beck (1987) studied the effects of long-term practice in decoding on various measures of reading ability. Positive effects were found for word reading, pseudoword reading, and text comprehension. The improvement generalized to nonpracticed words and nonpracticed tasks. Effects of training were particularly salient for poor read- 


\section{Poor readers' decoding skills: Effects of training witb limited exposure duration}

THERE IS ample evidence that a failure to decode words rapidly lies at the heart of reading difficulty. To improve poor readers' decoding speed, practice under time pressure is often recommended. The assumption that such training is better than a conventional type of training is addressed experimentally in this study. Young poor readers (mean age 9;11 years) received training in decoding monosyllabic pseudowords. One group saw the pseudowords briefly; an- other group practiced without time pressure. A third group received no training. Limiting the exposure duration appears to increase processing speed on trained and untrained material without costs in precision. The finding that gains in processing speed are lengthindependent has significant implications for decoding models. The observation that training without time pressure appears to slow down word processing speed is important for remedial practice.

\section{Habilidades de decodificacion en lectores con dificultades: Efectos de un entrenamiento con exposicion limitada}

EXISTE ABUNDANTE evidencia acerca de que la imposibilidad de decodificar rápidamente las palabras está en la base de las dificultades de lectura. Para mejorar la velocidad de decodificación de lectores con dificultades se recomienda a menudo la práctica bajo la presión del tiempo. En este estudio se examina experimentalmente el supuesto de que ese tipo de entrenamiento sea mejor que un entrenamiento convencional. Niños con dificultades de lectura (edad promedio 9;11 años) recibieron entrenamiento en decodificación de pseudopalabras monosilábicas. Un grupo vió las pseudopalabras por un breve período; otro grupo practicó sin presión de tiempo. Un tercer grupo no realizó entrenamiento. Limitar la duración de la exposición parece aumentar la velocidad de procesamiento tanto para el material ejercitado como para el no ejercitado sin costos en la precisión. El hallazgo de que los aumentos en la velocidad de procesamiento son independientes de la longitud tiene implicancias significativas para los modelos de decodificación. La observación de que el entrenamiento sin presión de tiempo parece disminuir la velocidad de procesamiento de palabras es importante para las prácticas de recuperación.

\section{Die Entscblïsselungsfäbigkeit scbwacber Leser: Effekte des Trainings mit begrenzter Lesewabrnebmungsdauer}

ES GIBT weite Übereinstimmung darin, daß das Versagen beim schnellen Decodieren von Wörtern ein grundlegendes Kennzeichen von Leseschwierigkeiten ist. Um die Decodierungsgeschwindigkeit bei schwachen Lesern zu erhöhen, werden oft Übungen unter Zeitdruck empfohlen. Die Annahme, daß ein solches Training wirkungsvoller ist als konventionelle Übungen, wird in dieser Studie experimentell geprüft. Mit jungen, schwachen Lesern im Durchschnittsalter von 9 Jahren wurde das Lesen von einsilbigen Pseudowörtern geübt. Eine Gruppe erkannte diese Pseudowörter nach kurzer Zeit, eine andere Gruppe übte ohne Zeitdruck. Die dritte Gruppe bekam keine Übungen. Die Konfrontation über begrenzte Zeit scheint die Verlaufsgeschwindigkeit bei geübtem und ungeübtem Material zu steigern, ohne Verlust an Präzision. Der Befund, daß der Schnelligkeitsgewinn unabhängig von der Rezeptionsdauer ist, hat bedeutende Implikationen für das Decodieren von Modellen. Die Beobachtung, daß Training ohne Zeitdruck die Lesegeschwindigkeit herabsetzt, ist folgenreich für Abhilfemaßnahmen. 


\section{読めない生徒の読字能力：接する時間を制限することによる練習効果}

単語が速く読字できない主な原因は 読解の難しさによるものであるとする 証撷はたくさんある。読めない生徒の 読字スピードを高めるために時間的制 限を与えた楝習がよく推翼されている。 この研究ではこうした練習の方が従来 のタイプの練習より効果があるという 仮説が实臸を通して述べられている。 年餄層の低い読めない生徒たち（平均 年(鸰9才 11 力月) が単音節の疑似単 語を読字する訓楝を受けた。1つのグ ループはその䈝似単語を短い時間で見 る訓绳をし、もう 1 つのグルーブは時
間的制限を与えられずに楝習した。そ して3番目のグループは何の訓瑓も受 けなかった。接する時間を制限した方 が楝習した題材と練習しなかった題材 の両方において正確さの程度を落とす ことなく処理スピードを高めたようで ある。処理スピードが高まるのは長さ に関係ないという実験結果は讙字モデ ルに対して意味のある示唆を与えるも のである。時間的制限を与えないと単 語の処理スピードが遅くなるようであ るという瞴察記録は㭪修のための瑓習 には重要なことである。

\section{Le décodage des mauvais lecteurs: effets d'un entraînement à durée d'exposition limitée}

IL $\mathrm{Y}$ a de nombreuses preuves que l'échec dans le décodage rapide des mots est au coeur des difficultés de lecture. Pour améliorer la vitesse de décodage des mauvais lecteurs, on recommande souvent un entraînement comportant une pression temporelle. Cette étude expérimentale s'intéresse au présupposé qu'un tel entrainement est supérieur à un entraînement de type conventionnel. De jeunes mauvais lecteurs (moyenne d'âge: 9;11 ans) ont reçu un entraînement au décodage de pseudo-mots monosyllabiques. Un groupe a vu les pseudo-mots brièvement; un autre groupe a travaillé sous pression temporelle. Un troisième groupe n'a pas reçu d'entrainement. La limitation de la durée d'exposition apparaît augmenter la vitesse de traitement, avec un matériel avec lequel on a été ou non entraîné, sans préjudice pour la précision. La fait que les gains en vitesse de lecture soient indépendants de la longueur a d'importantes implications pour les modèles de décodage. L'observation que l'entraînement sans pression temporelle apparaisse ralentir la vitesse de traitement des mots est important pour les pratiques de rééducation. 
ers. In contrast, Lovett, Warren-Chaplin, Ransby, and Borden (1990) found better results for a whole-word procedure than for decoding training, but their suggestion may be correct that reading-disabled children need a different and more explicit decoding training than the one offered in their study. After all, even their decodingoriented training may have favoured the application of whole-word strategies, as half of the words were instructed by means of whole-word methods, and all words were presented again in a reviewing procedure (cf. van Bon, in press).

The observation that poor readers have difficulty with phonological decoding and that training this skill has positive effects on reading ability provides evidence for a causal relationship (Wagner \& Torgesen, 1987). The consequence is that poor readers should learn to decode words quickly and without effort. This raises the issue of how to design training programs in order to achieve that goal. It may be argued that some forms of training are more effective than others. Some issues regarding the design of training in phonological decoding will be discussed below.

An important question is whether decoding skills can be trained more effectively by reading words in isolation or in the context of sentences. Stanovich (1980) has argued that poor readers in particular are likely to utilize context as an aid for word identification in order to compensate for their weak decoding skills. There is substantial empirical evidence for this position (e.g., Briggs, Austin, \& Underwood, 1984; Perfetti \& Roth, 1981; West \& Stanovich, 1982). Thus, in order to prevent poor readers from bypassing the phonological decoding route by relying on context, training should employ a single-word reading task.

Similarly, decoding skills may be trained more effectively by reading pseudowords rather than by reading words. When reading words, poor readers tend to evade decoding, relying instead on lexical sources of information (Stanovich, 1980). Pseudoword reading however, compels readers to decode and minimizes the influence of lexical facilitation.

A next issue is what aspect of decoding should be practiced in order to obtain a maximum learning effect. There is general consensus that for many children, reading difficulties are primarily characterized by slow, rather than by inaccurate decoding (e.g., Ehri \& Wilce, 1983; Perfetti, 1985). Poor readers may be accurate decoders but execute this skill so slowly and with such demands on capacity that it exhausts the available cognitive resources (Stanovich, 1986). If slow rule application rather than lack of knowledge is the core of the decoding problem, remediation that aims to improve decoding speed should prove to be a more fruitful approach than emphasizing accuracy. This prediction will be tested in the present study.

Improving decoding speed may be accomplished by training in reading under time pressure: by limiting the exposure duration of words, the time available for responding, or both. When a child is trying to read a briefly presented word, a grapheme-by-grapheme decoding strategy is likely to fail. This may cause children to adopt a different decoding approach, possibly by using multigrapheme units (LaBerge \& Samuels, 1974). Pressure upon the child to respond quickly may have positive effects on later phases in word recognition, like blending processes.

Time pressure is widely used in the remediation of reading problems, with the flashcard method as probably the best known example. In this task, single high-frequency words are briefly presented on cards or computer monitor. The child has to read the words aloud. The idea is that limited exposure duration has a beneficial effect on the identification speed because it prevents children from dawdling and breaking words in too many parts. Despite its use in practical settings, little is known about the effects of time pressure during training. Recently, we addressed this question experimentally (van den Bosch, van Bon, \& Schreuder, 1990). We manipulated time control on the reading process during training and examined the effects upon young poor readers' word identification skills. Two forms of time control were compared, the exposure duration and response preparation time. Each factor had two levels. Exposure duration was either limited or unlimited, and the child was either instructed to respond quickly or not (response speeding vs. no response speeding). The orthogonal combination of both factors produced four different training programs. Children received practice in reading aloud words and pseudowords twice a week for a period of 2 months. Training effects were assessed by two standard reading tasks and by a picture-word interference task (cf. Schadler \& Thissen, 1981). The best results were obtained by the program in which children practiced to read briefly presented words and pseudowords without the instruction to respond quickly. Limited exposure duration seems therefore to be the most efficient form of time pressure during training. Conclusions with respect to the profits from such a training were restricted, however, because the experimental design lacked a control group that did not receive training.

The purpose of the present study is to repeat part of the earlier study in order to test whether training in decoding under conditions of limited exposure duration is more beneficial than a more conventional type of training - that is, practice in reading words as accurately 
Table 1 Number of pseudowords of each orthographical structure and of each presentation frequency

\begin{tabular}{|c|c|c|c|c|c|c|c|c|c|}
\hline \multirow[b]{3}{*}{ Frequency } & \multicolumn{9}{|c|}{ Orthographical structure } \\
\hline & \multicolumn{3}{|c|}{ CVCC } & \multicolumn{3}{|c|}{ CCVC } & \multicolumn{3}{|c|}{ CCVCC } \\
\hline & npw & npres & nses & npw & npres & nses & npw & npres & nses \\
\hline 1 & 128 & 128 & (8) & 128 & 128 & (8) & 256 & 256 & (16) \\
\hline 4 & 32 & 128 & (8) & 32 & 128 & (8) & 64 & 256 & (16) \\
\hline \multirow[t]{2}{*}{8} & 16 & 128 & (8) & 16 & 128 & (8) & 32 & 256 & (16) \\
\hline & 176 & 384 & (24) & 176 & 384 & (24) & 352 & 768 & (48) \\
\hline
\end{tabular}

Note. Frequency $=$ number of presentations per 16 sessions. $\mathrm{npw}=$ number of pseudowords. npres $=$ number of presentations across program

$=$ frequency $\times$ npw. nses $=$ number of pseudowords per session.

as possible and without constraints on the exposure duration. Effects are investigated by studying reading variables during training and with independent reading tasks administered prior to and after training.

The verbal efficiency model (Perfetti, 1985) states that there is a strong relation between decoding and lexical access on the one hand and text comprehension on the other. The strong version of the verbal efficiency model predicts that progress in decoding brings about improvement in comprehension. A sentence verification task was used to investigate this hypothesis.

\section{Metbod}

\section{Subjects}

Subjects were selected from two schools for children with learning disabilities. The children were qualified by their teachers as "poor readers," lagging 1 to 2 years in reading development. In order to verify whether subjects had acquired elementary knowledge of grapheme-phoneme correspondences, children were required to read aloud a list of $34 \mathrm{VC}$ pseudowords. The list contained all vowels used in training, as well as all legitimate final consonants in Dutch. Only children who could read all VC pseudowords correctly participated in the experiment. A total of 62 children ( 43 boys, 19 girls) met this criterion. Their ages ranged from $7 ; 8$ to $12 ; 8$ years, with a mean of $9 ; 11$ years ( $S D=13$ months). The reading methods used in their schools are basically phonics oriented.

\section{Design}

A pretest-training-posttest design was used. The subject sample was divided into three groups, matched on two pretest measures: (a) accuracy in pseudoword naming and (b) automaticity of pseudoword decoding.
Two groups consisted of 21 subjects, one group of 20 subjects. Groups were randomly assigned to one of three training conditions: limited exposure duration (flashcard group), unlimited exposure duration (reading aloud group), and a control condition in which no training was given (no training group). The subjects in this latter group participated in pre- and posttests only.

\section{Apparatus}

An Apple IIGS computer was used. Pseudowords were presented in black, lower-case letters on a white background in the center of the screen. A four-letter string measured approximately 3 by $0.7 \mathrm{~cm}$. Children were seated circa $60-80 \mathrm{~cm}$ from the screen. Naming latencies of correct responses were registered by means of a voice-activated relay attached to the computer. Sentence verification latencies were recorded by means of a device with two buttons (a yes and a no button), which was also connected to the computer.

\section{Training: Materials and procedure}

Monosyllabic pseudowords with one or two consonant clusters (CVCCs, CCVCs, and CCVCCs) were used in the flashcard and the reading aloud conditions. In order to reduce possible lexical facilitation in pseudoword reading (Pring \& Snowling, 1986; Stanners \& Forbach, 1973), only pseudowords that differed from high-frequency words in more than one letter were selected. High-frequency words have a printed frequency count of more than five per million (Staphorsius, Krom, \& de Geus, 1989). A second criteria for pseudoword selection was that the positional grapheme frequency matched the positional grapheme frequency of monosyllabic Dutch words (Bakker, 1972). Thus, pseudowords were orthographically dissimilar to individual high-frequency words, but were similar to these words with respect to the distribution of graphemes. Three lists were construct- 
ed, consisting of 422 CVCC, 196 CCVC, and 386 CCVCC pseudowords, respectively. Examples can be found in Appendix A.

The training programs consisted of 16 training sessions of approximately $25 \mathrm{~min}$ each. Subjects practiced individually twice a week, for 8 weeks in total. In each session 96 pseudowords were presented, one at a time. The total training program consisted of $176 \mathrm{CVCC}$, 176 CCVC, and 352 CCVCC pseudowords. These pseudowords were, for each subject, randomly selected from the respective pseudoword files. This reduces the risk of obtaining results confounded by word-specific effects. Pseudowords were presented 1,4 , or 8 times during the program. Successive presentations were spaced with equal intervals across the program. Thus, a pseudoword of the 8 presentations condition reappeared on alternate sessions. Table 1 shows the number of pseudowords across the entire program and the number of pseudowords per session in parentheses. Presentation order within sessions was randomized.

Subjects were instructed to name each pseudoword. A maximum of $6.5 \mathrm{~s}$ was allowed for responding. Each trial started with a 50-ms beep, followed by an asterisk that remained for $500 \mathrm{~ms}$ in the center of the screen. Children were told to focus on the asterisk. The pseudoword appeared on the screen in the same location as the asterisk. Exposure duration of the pseudoword was dependent on the training condition (see below). Naming latency was defined as the time between the onset of presentation and the verbal response of the subject that triggered the voice key. Subjects' responses were evaluated by the experimenter. Because in Dutch there is a rather transparent relation between orthography and phonology, uncertainty about the accuracy of the child's response was rare. Minor deviations in pronunciation due to local accent were ignored. In case of an incorrect response, the word FOUT [wrong] was shown for one second. A correct response was followed by verbal approval of the experimenter. At the end of each session, the computer provided feedback about the child's performance (mean exposure duration for the flashcard group, number correct for the reading aloud group). This information enabled subjects to see whether they improved during the program. At the start of each session, the experimenter tried to motivate the children to improve their performance. Although response latency data were collected, no allusion was made to response speed when giving instruction or feedback.

Flashcard training. In the flashcard program, reading was put under time pressure by presenting the pseudowords briefly. In order to adjust the amount of time pressure to fit the child's capacities, the exposure duration was controlled on-line as a function of accuracy, for each child individually, in such way that the accuracy rate was maintained at a constant level of approximately $67 \%$. As can be seen in Table 1, the within-subjects design has six cells (two levels of Orthographical Structure, and three levels of Presentation Frequency). For each cell, the accuracy rate was maintained at a constant level by varying the exposure duration. After each trial, accuracy of the current pseudoword and the previous two pseudowords of the same cell were evaluated. Exposure duration for items from that cell was increased with 17 $\mathrm{ms}$ when two or more errors were made, and was decreased with $17 \mathrm{~ms}$ if no errors were made. If two out of three pseudowords had been read correctly, exposure duration remained unchanged. Each session started with the exposure durations with which the previous session had ended. Initial exposure duration was determined for each subject in a presession, using an adaptation procedure comparable to that of the training but with steps of $68 \mathrm{~ms}$, and with similar but not the same pseudowords.

When exposure duration expired, the pseudoword was masked by nonletter symbols for $1.5 \mathrm{~s}$. The mask remained on the screen until a response was given or until maximum trial time had expired.

Reading aloud training. Exposure duration was unlimited in the reading aloud training. Pseudowords were shown on the screen until the subject produced a verbal response that triggered the voice key or until the maximum time for responding had expired. Then the pseudoword was masked by nonletter symbols for $1.5 \mathrm{~s}$. Subjects in this condition also received a presession, with pseudowords similar to those in the training and a procedure that was identical to the one used during training sessions.

\section{Pre- and posttests}

A pseudoword naming task was used to investigate the effects of training on decoding accuracy and decoding speed. A word naming task was used to examine effects of training in pseudoword decoding on accuracy and speed of "normal" word identification. A pictureword interference task was used in order to investigate whether training affected automaticity of word and pseudoword processing. A sentence verification task was used to examine whether training in decoding would affect text comprehension performance.

Pseudoword reading test. For each of the three levels of presentation frequency (1, 4, and 8), 20 pseudowords were randomly selected from the training material, for each subject individually. Twenty pseudowords that had not been presented during training were added. The 80 pseudowords in total (20 CVCCs, 20 CCVCs, and 40 CCVCCs) were presented, one at a time, on the computer screen. The task was to read the pseudowords 
Table 2 Adjusted posttest means of number correct and naming latency (in milliseconds) on pseudoword reading, split by orthographical structure

\begin{tabular}{lccccccc}
\hline \hline & \multicolumn{3}{c}{ Number correct $^{a}$} & & \multicolumn{3}{c}{ Latency (in ms) } \\
\cline { 2 - 3 } Group & CVCC/CCVC & CCVCC & Mean & & CVCC/CCVC & CCVCC & Mean \\
\hline Flashcards $(n=20)$ & 35.4 & 34.7 & 35.1 & & 1826 & 2092 & 1959 \\
Reading aloud $(n=21)$ & 35.0 & 34.8 & 34.9 & & 2124 & 2428 & 2276 \\
No training $(n=21)$ & 28.0 & 26.9 & 27.5 & & 2021 & 2206 & 2114 \\
\hline
\end{tabular}

a Maximum $=40$.

aloud, as accurately and quickly as possible. Exposure duration was unlimited. Accuracy and response latencies were determined.

Word reading test. Three sets of words $(54 \mathrm{CVCCs}$, 54 CCVCs, and 76 CCVCCs) with a printed frequency count of more than 50 occurrences per million were selected from Staphorsius et al. (1989). All words were orthographically regular. Examples can be found in Appendix B. For each subject, 16 CVCC, 16 CCVC, and 32 CCVCC words were randomly selected from these sets. They were presented, one at a time, on the computer screen. The instruction was again to read the words aloud, as accurately and quickly as possible. Exposure duration ended with the response of the subject or when the maximum of $6.5 \mathrm{~s}$ allowed for responding expired. Accuracy and response latencies were recorded.

Picture-word interference test. Forty-eight pictures of common objects and animals were selected. The same number of distractor triplets, consisting of a word, a pseudoword, and a consonant string, were created. For each subject, 16 pseudoword distractors (4 CVCCs, 4 CCVCs, and 8 CCVCCs) were randomly selected from each level of Presentation Frequency.

For each subject, $12 \mathrm{CVCC}, 12 \mathrm{CCVC}$, and 24 CCVCC words were selected from the word lists (see Word Reading) such that each word distractor matched a pseudoword distractor in length, orthographical structure, and initial consonant. None of these words was used in the word reading task.

Finally, to each of the 48 word and pseudoword pairs, a consonant string of the same length and with the same initial consonant was added. Prior to the testing proper, subjects were shown all the pictures to be used in this task (without distractors) and were asked to name them aloud. This was to ensure that subjects knew the names of all pictured objects and animals. Naming errors were rare, but when they occurred, the experimenter provided the correct label.
In the testing proper, children were told that they would see a picture with a letter string superimposed. Their task was to ignore the letters and to name the picture as quickly as possible. Pictures were paired randomly with a distractor triplet. Presentation order of the $(48 \times 3) 144$ trials was randomized for each subject separately with the constraint that a picture was not to occur twice within 24 trials. Each trial started with a 50-ms beep followed by a fixation asterisk in the center of the screen $(500 \mathrm{~ms})$. Then, the picture and distractor appeared simultaneously on the screen in the same location as the asterisk. Both remained on the screen until a response was made. Naming latency was determined for each correct response. Experimental trials were preceded by 18 practice trials.

Sentence verification test. Thirty semantically correct sentences (e.g., kaas is geel [cheese is yellow]) and 10 semantically incorrect sentences (e.g., een kat is een plant [a cat is a plant]) were shown one by one, in random order, on the screen. Sentences consisted exclusively of frequent monosyllabic regular words. A sample of sentences used for this task can be found in Appendix C. The subjects' task was to indicate as fast as possible by pressing a button whether the sentence was correct or incorrect. They were allowed to use their preferred hand at the yes button. Exposure duration was unlimited. Each subject received a different randomization of the 40 trials. Number and latency of correct responses were recorded.

\section{Results}

\section{Pre- and posttests}

For all tasks and for each subject, median latency and accuracy scores were calculated for each experimental within-subjects condition. Latencies of incorrect responses or responses that probably contained timing errors were not used.

No significant group differences were found on 
Table 3 Adjusted posttest means of number correct and naming latency (in ms) on word reading, split by orthographical structure

\begin{tabular}{lccccccc}
\hline \hline & \multicolumn{3}{c}{ Number correct $^{\mathrm{a}}$} & & \multicolumn{3}{c}{ Latency (in ms) } \\
\cline { 2 - 3 } Group & CVCC/CCVC & CCVCC & Mean & & CVCC/CCVC & CCVCC & Mean \\
\hline Flashcards $(n=20)$ & 30.1 & 28.7 & 29.4 & & 1094 & 1462 & 1278 \\
Reading aloud $(n=21)$ & 29.8 & 28.9 & 29.3 & & 1278 & 1776 & 1527 \\
No training $(n=21)$ & 29.2 & 27.4 & 28.3 & & 1166 & 1442 & 1304 \\
\hline a & & & & & & &
\end{tabular}

$\mathrm{a}_{\text {Maximum }}=32$.

any of the pretest measures, but in order to reduce error variance attributable to any between-groups differences prior to training, analyses were carried out on adjusted posttest scores if pretest and posttest scores were highly correlated (cf. Hand \& Taylor, 1987, p. 163). Therefore, pretest scores were included as covariates in all analyses of variance with exception of those on the picture-word interference test data, as the correlation between preand posttest scores was very low for that test $(r=.02$, n.s.). The magnitude of treatment effects on latency and accuracy is presented as the effect-size (ES) (Cohen, 1988 , p. 275; for planned comparisons: p. 20).

Pseudoword reading. Van den Bosch et al. (1990) demonstrated that children performed similarly on naming CVCC and CCVC pseudowords. Therefore, in this study, CVCC and CCVC pseudowords were collapsed and analyzed together. Median latency and number correct on the posttest were submitted to a multivariate analysis of variance with Treatment (3) as betweensubjects factor and Orthographical Structure (2) as within-subjects factor. Posttest means, adjusted for pretest differences, are displayed in Table 2.

A main effect of Treatment was found, $F(4,112)=$ $13.59, p<.01$. Univariate results showed significant effects for latency as well as for accuracy, $F(1,57)=4.7$, $p<.05, \mathrm{ES}=.15$ and $F(1,57)=151, p<.01, \mathrm{ES}=.68$, respectively. A comparison between the flashcard and the reading aloud groups revealed that a training with limited exposure duration tended to result in shorter response latency (1959 vs. $2276 \mathrm{~ms}, F[1,57]=3.63, p<.07$, $\mathrm{ES}=.36$ ), but no difference with respect to accuracy was found $(F<1)$. The flashcard group read more words correctly than the no training group, 35.1 vs. $27.5, F(1,57)=$ $45.8, p<.01, \mathrm{ES}=1.46$. The difference in latency between these groups, however, was not significant, $F(1,57)=1.6, p=.21$.

A main effect of Orthographical Structure $(F[2,56]=$ $17.1, p<.01)$ indicates that CCVCCs were harder to read than CVCC/CCVCs. Univariate analyses revealed that orthographical structure had no effect on accuracy $(F<1)$, but children responded faster to CVCC/CCVCs than to
CCVCCs (1990 vs. $2242 \mathrm{~ms}, F[1,57]=34.6, p<.01)$. The interaction between Orthographical Structure and Treatment was not significant $(F<1)$.

In order to test whether repeated presentation during training enabled children to respond faster and more accurately to pseudowords, median latency and number correct on the posttest were subjected to a similar multivariate analysis that included Presentation Frequency (8, 4 , and 1 presentations) as a within-subjects factor, again with pretest scores as a covariate, but with the no training group excluded.

The three-way interaction among Treatment, Orthographical Structure, and Presentation Frequency approached significance, $F(4,27)=2.59, p=.06$. Univariate analysis revealed that for the reading aloud group, the beneficial effect of repeated presentation on naming latency was not affected by orthographical structure, whereas for the flashcard group, repeated presentation had a beneficial effect on naming latency for CVCC/CCVCs, but not for CCVCCs, $F(1,30)=9.22$, $p<.01$. The interaction between Orthographical Structure and Presentation Frequency was not significant $(F<1)$. Furthermore, the interaction between Treatment and Presentation Frequency approached significance, $F(4,130)=2.17, p=.08$. Univariate analyses demonstrated that the beneficial effect of repeated presentations on accuracy tended to be larger for the flashcard group than for the reading aloud group, $F(2,66)=2.72, p=.07$. No effect for the latency variable was found $(F<1)$. Finally, a main effect of Presentation Frequency was found, $F(4,27)=3.31, p<.05$. Univariate analysis demonstrated that repeated presentations had no effect on latency $(F<1)$, but had a significant positive effect on accuracy, $F(2,66)=9.42, p<.01$. The nature of this effect was linear, as indicated by a significant linear component, $F(1,30)=8.94, p<.01$. This suggests that the beneficial effect of repeated presentations on accuracy was not yet at its maximum with eight occurrences during training.

Word reading. Median latency and number correct on the posttest were submitted to a multivariate analysis of variance with Treatment (3) as between-subjects fac- 
Figure 1 Pseudoword interference [left panel] and word interference [right panel] (in ms) on pre- and posttest for each condition

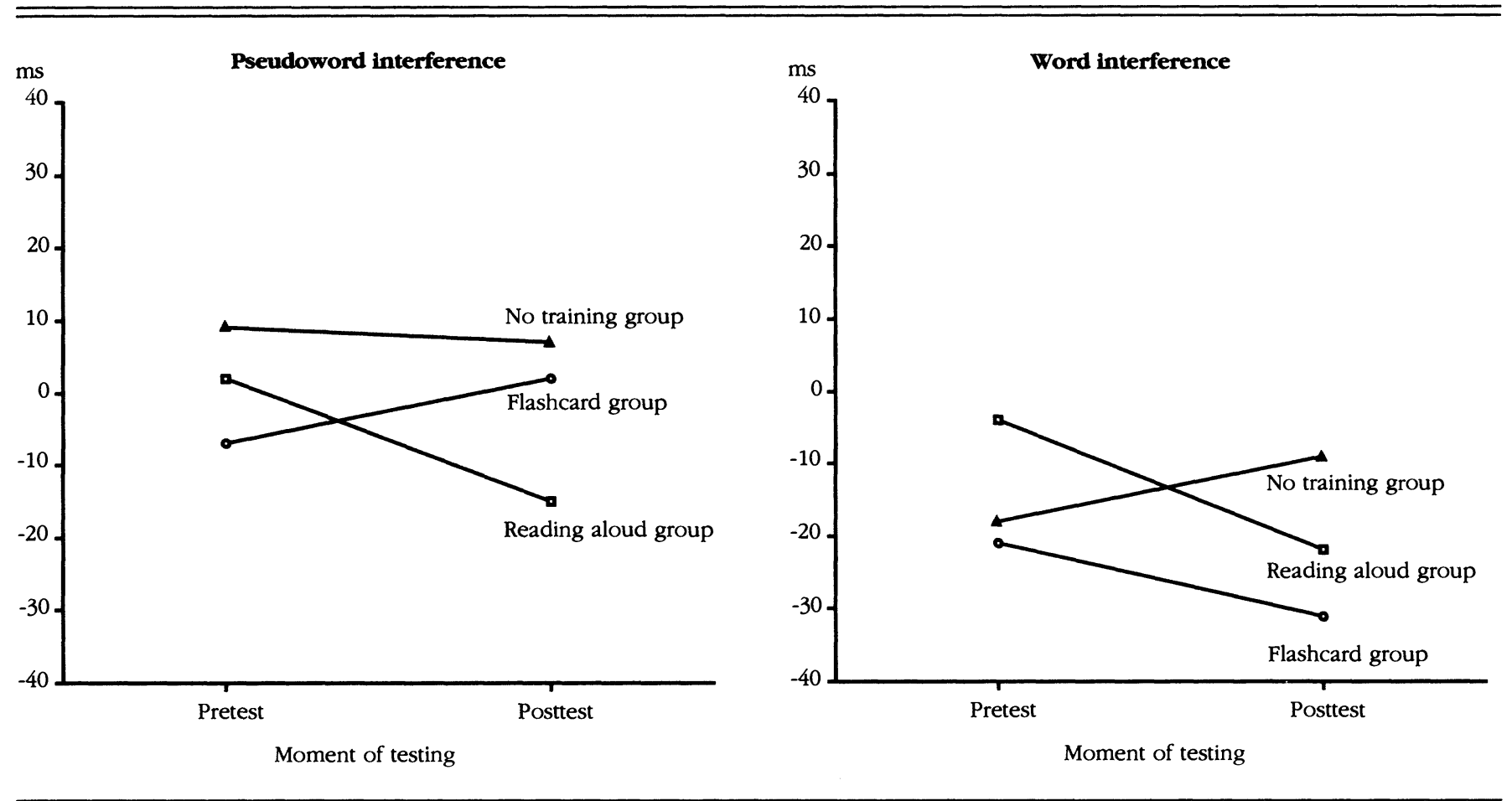

tor and Orthographical Structure (2) as within-subjects factor. Pretest scores served as covariates. Posttest means, adjusted for pretest differences, are displayed in Table 3 .

A main effect of Treatment was found, $F(4,110)=$ $2.81, p<.05$. Univariate results showed that the three training groups tended to differ in naming latency $(F[2,56]=3.09, p=.05, \mathrm{ES}=.2)$, but not in accuracy $(F[2,56]=1.96, p=15)$. The flashcard group responded faster than the reading aloud group (1278 vs. $1527 \mathrm{~ms}$, $F[1,56]=5.27, p<.05, \mathrm{ES}=.46)$, but these groups did not differ with respect to accuracy $(F<1)$. Furthermore, the flashcard group tended to read more words correctly than the no training group $(29.4$ vs. $28.3, F[1,56]=3.64$, $p=.06, \mathrm{ES}=.42$ ), but no group differences in naming speed were found $(F<1)$.

The interaction between Orthographical Structure and Treatment was not significant $(F<1)$. The main effect of Orthographical Structure $(F[2,55]=8.44, p<.01)$ indicates that CCVCCs were harder to read than CVCC/ CCVCs. Univariate analyses revealed that CCVC/CCVCs were read both faster and more accurately than CCVCCs (1179 vs. $1560 \mathrm{~ms}, F[1,56]=4.34, p<.05$, and 29.7 vs. 28.3 words correct $F[1,56]=12.26, p<.01$ ).
Picture-word interference test. Word and pseudoword interference were defined as the delay in naming pictures printed with words and pseudowords, respectively, relative to naming of pictures printed with consonant strings. Word and pseudoword interference on the pre- and posttest is represented in Figure 1. As argued earlier, the posttest scores on this test were not adjusted for pretest differences.

Prior to training, no differences between groups were found $(F<1)$. Pseudoword interference did not differ significantly from zero $(F<1)$, suggesting that children named pictures with superimposed pseudowords as fast as pictures with consonants strings. However, naming latency tended to be shorter for pictures with words than for pictures with consonant strings, $F(1,58)=2.79, p=1$.

In order to test whether groups differed after training, analyses of variance were carried out with pseudoword and word interference as dependent variables and with Treatment (3) as between-subjects factor. No effect of Treatment was found $(F<1)$. Again, pseudoword interference did not differ significantly from zero $(F<1)$. Children were $20 \mathrm{~ms}$ faster in naming pictures with words than naming pictures with consonant strings, $F(1,59)=$ $5.63, p<.05$. This outcome is rather peculiar, but a similar 
effect was suggested by the pretest data. Of central interest, however, is whether the effect from words on picture naming changed from pre- to posttest. This question was addressed by calculating the difference in word interference between pre- and posttest and entering this variable in a new analysis of variance. The constant component in this variable was not significant $(F<1)$, indicating that training did not affect word interference. In addition, no effect of Treatment was found $(F<1)$, demonstrating that groups did not differ in that respect. An analysis of variance to examine the effects of number of exposures to a pseudoword on the interference of that pseudoword on picture naming showed no significant effects related to this factor (all $F \mathbf{s}<1$ ).

Sentence verification test. Accuracy scores on the pretest were near ceiling level for all three groups. For this reason accuracy measures were not analyzed. Median posttest latencies of responding to true and false sentences were submitted to an analysis of variance with Treatment (3) as between-subjects factor and Type of Sentence (2) as within-subjects factor. Pretest latencies served as covariates. Posttest means adjusted for pretest differences are displayed in Table 4.

The effect of Treatment was not significant, $F(2,57)=1.21, p=31$. Comparisons between the flashcard group and the reading aloud group and between the flashcard group and the no training group were both nonsignificant, $F(1,57)=2.38, p=.13$, and $F<1$, respectively. Children needed substantially more time to reject a semantically incorrect sentence than to accept a semantically correct one, as indicated by a significant main effect of Type of Sentence, 4862 vs. $3776 \mathrm{~ms}, F(1,57)=$ $7.13, p<.01$. No interaction with the between-subjects factor was found $(F<1)$.

\section{Training data}

The reading aloud group read $87 \%$ of the pseudowords correctly, and the flashcard group $70 \%$. The flashcard group should, as a result of the adopted procedure, read $67 \%$ of the pseudowords correctly, but as children improved during training, this percentage was a little higher.

The subject's median naming latency was calculated for each session. Also, the median exposure duration of each session was calculated for each subject in the flashcard group, and the number of correctly named pseudowords was determined for each subject in the reading aloud group. These dependent measures were assessed for all six cells of the within-subjects design separately.

The 16 training sessions were divided into four blocks of four sessions each. Means were calculated for
Table 4 Adjusted posttest latency (in ms) of correct responses on the sentence verification task, split by semantically true and false sentences

\begin{tabular}{lcc}
\hline \hline Group & True sentences & False sentences \\
\hline Flashcards $(n=20)$ & 3619 & 4696 \\
Reading aloud $(n=21)$ & 3894 & 5105 \\
No training $(n=21)$ & 3816 & 4785 \\
\hline
\end{tabular}

each training block. These data were entered in analyses of variance.

Latency. Naming latencies were submitted to an analysis of variance with Treatment (2) as between-subjects factor. Effects of Time ( 4 training blocks), Presentation Frequency (3) and Orthographical Structure (2) were tested within subjects.

The flashcard group responded much faster than the reading aloud group, $F(1,39)=18.04, p<.01, \mathrm{ES}=$ .38 . The main effect of Time $(F[3,37]=6.44, p<.01)$ indicates that naming speed increased over training. The interaction between Treatment and the linear component of Time was significant, $F(1,39)=5.15, p<.05$. Figure 2 shows that the decline of response latency was steeper for the reading aloud group than for the flashcard group.

Figure 2 Pseudoword naming latency (in ms) for both training groups, collapsed across orthographical structure and presentation frequency

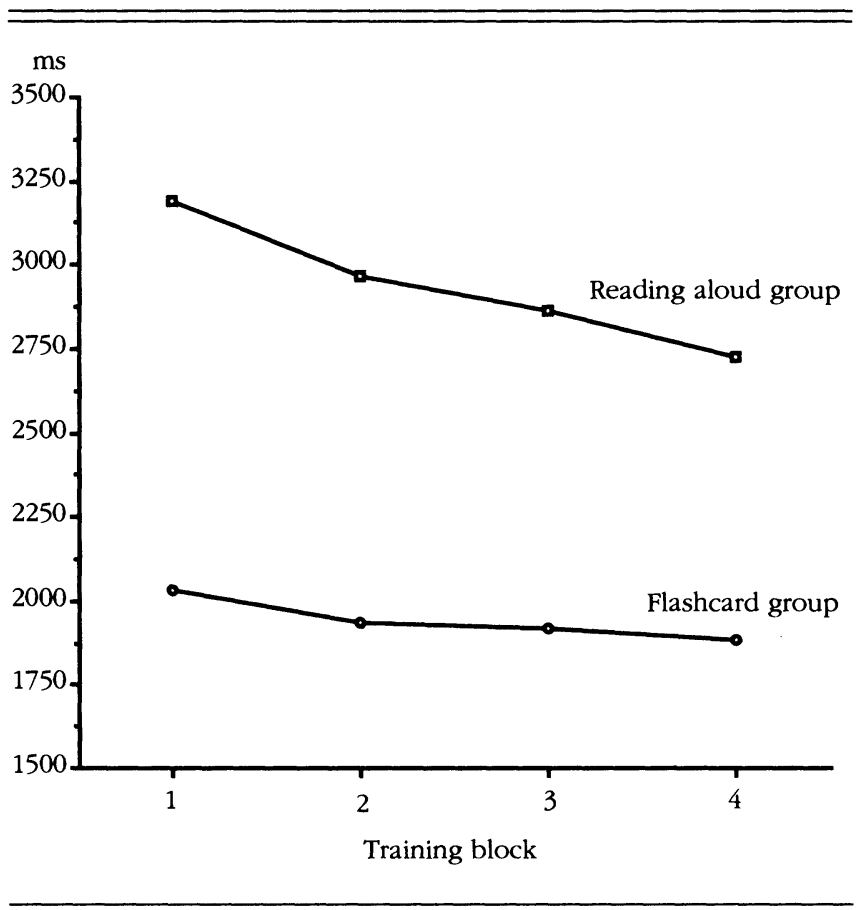


Figure 3 Pseudoword naming latency (in ms), split by orthographical structure and collapsed across presentation frequency and training groups

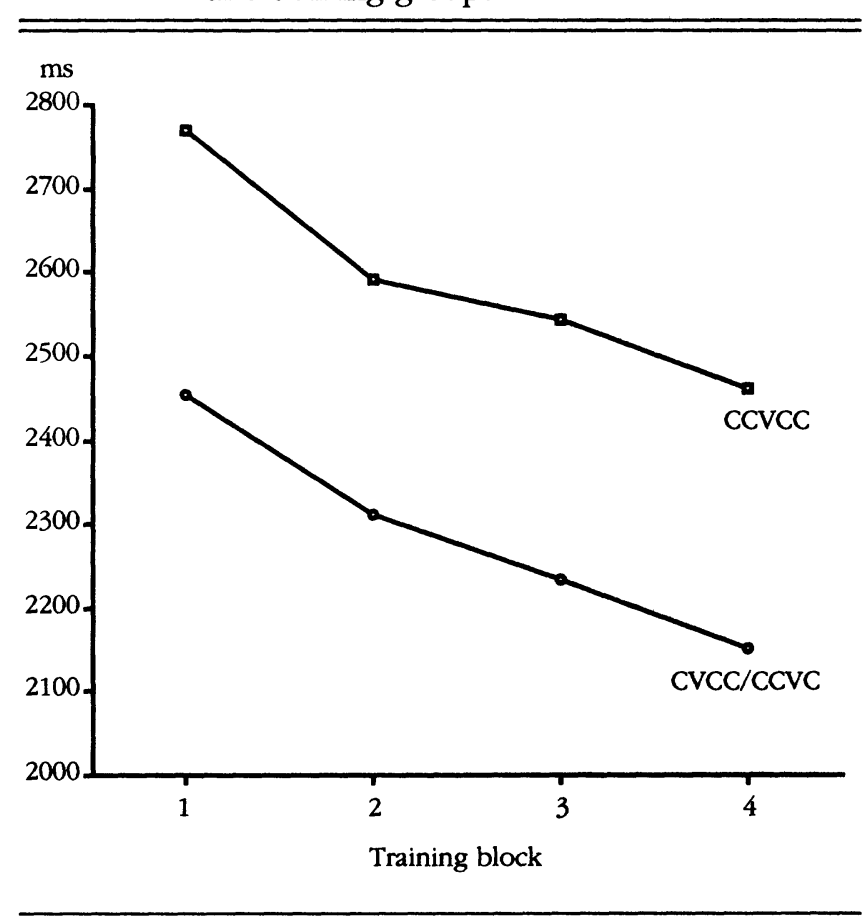

Repeated presentation affected the speed with which pseudowords were named, as indicated by a significant interaction between Time and Presentation Frequency, $F(6,34)=2.89, p<.05$. The three-way interaction among Treatment, Presentation Frequency, and Time was not significant $(F[6,34]=1.29, p=.29)$, indicating that the beneficial effect of repeated presentation on naming latency did not differ between training groups.

A main effect of Orthographical Structure was found $(F[1,39]=84.86, p<.01)$, indicating that subjects responded faster to CVCC/CCVCs than to CCVCCs. The interaction between Orthographical Structure and Treatment $(F[1,39]=12.64, p<.01)$ reveals that the difference between the orthographical structures was larger for the reading aloud group than for the flashcard group ( 420 vs. $187 \mathrm{~ms}$, respectively). However, this difference remained stable throughout the training program, as indicated by a nonsignificant three-way interaction among Treatment, Orthographical Structure, and Time, $F(6,34)$ $=1.80, p=.13$. The four-way interaction among Treatment, Presentation Frequency, Orthographical Structure, and Time was not significant either, $F(6,34)=$
1.29, $p=.29$. The absence of an interaction between Orthographical Structure and Time ( $F<1$, see Figure 3) indicates that the improvement in naming speed did not differ for CVCC/CCVCs and CCVCCs.

Exposure duration (flashcard group). Exposure durations were submitted to an analysis of variance with Time ( 4 training blocks), Presentation Frequency (3), and Orthographical Structure (2) as within-subjects factors. The overall exposure duration required to identify $67 \%$ of the presented pseudowords correctly decreased as the training program progressed, indicated by a significant effect of Time, $F(3,17)=54.31, p<.01$.

Repeated presentations reduced the required exposure duration on subsequent presentations, as demonstrated by the significant interaction between Time and Presentation Frequency, $F(6,14)=3.40, p<.05$. This beneficial effect was not affected by orthographical structure, as indicated by a nonsignificant three-way interaction among Time, Presentation Frequency, and Orthographical Structure $(F<1)$.

Naming double-cluster pseudowords required a longer overall exposure duration than naming singlecluster pseudowords, as demonstrated by a significant main effect of Orthographical Structure, $F(1,19)=10.93$, $p<.01$. However, no interaction between Orthographical Structure and Time was obtained $(F[3.17]=1.62, p=.22$; see Figure 4), indicating that the decrease of exposure duration across training did not differ for CVCC/CCVCs and CCVCCs.

Accuracy (reading aloud group). The number of pseudowords named correctly per training block was submitted to an analysis of variance. Time (4 training blocks), Presentation Frequency (3), and Orthographical Structure (2) were the within-subjects factors. Children improved their accuracy during training, as indicated by a main effect of Time, $F(3,18)=9.56, p<.01$.

Accuracy was not improved by presentations earlier in the training, as indicated by a nonsignificant interaction between Time and Presentation Frequency, $F(6,15)=1.37, p=.29$. This is in contrast to latency data, which did show a positive effect of repeated presentations. The three-way interaction among Time, Presentation Frequency, and Orthographical Structure was not significant either $(F<1)$.

The nonsignificant main effect of Orthographical Structure $(F<1)$ demonstrates that single-cluster pseudowords were read no more accurately than double-cluster pseudowords. The interaction between Orthographical Structure and Time was significant, $F(3,18)=3.70$, $p<.05$. Inspection of Figure 5 suggests that the effect of Time was smaller for double-cluster pseudowords than for single-cluster pseudowords. 


\section{Discussion}

The main purpose of this study was to investigate whether training in decoding under conditions of limited exposure duration is more beneficial than practice in reading words without constraints on the exposure duration. Results suggest that young poor readers' word identification skills can be improved by training in pseudoword decoding provided that children practice under conditions of limited exposure duration. If no limits are set to the presentation time, training appears to have negative rather than positive effects. The results with respect to pre- and posttests will be discussed first, followed by a discussion of data from the training itself.

The flashcard group achieved a higher level of accuracy than the no training group, with respect to both word and pseudoword reading. The accuracy gains were not achieved at the expense of speed, as indicated by nonsignificant differences in naming latencies. A comparison between the two training groups revealed that the flashcard group was faster than the reading aloud group at reading words, and tended to be faster at reading pseudowords. Likewise, the superior naming speed of the flashcard group was not achieved at the expense of precision, as indicated by nonsignificant group differences with respect to accuracy.

An unexpected outcome was the poor performance of the reading aloud group. Posthoc analyses revealed that they were considerably slower than the no training group at reading words, $223 \mathrm{~ms} ; F(1,57)=6.16$, $p<.05, \mathrm{ES}=.41$. They appear to be slower at reading pseudowords too $(162 \mathrm{~ms})$, but this difference was not statistically significant, $F(1,58)=2.38, p=.13$, ES $=.19$.

The relatively fast processing of the flashcard group, and the slow processing of the reading aloud group may be explained as follows. Neither the flashcard group nor the reading aloud group was instructed to respond quickly, but both groups were instructed to read as many pseudowords correctly as possible. At the end of each training session, however, only the children of the reading aloud group received feedback with respect to accuracy (the number correct of the flashcard group was experimentally maintained at about $67 \%$ ). The combination of the instruction to read accurately, unlimited processing time, and feedback on number correct in the reading aloud group may have induced children to adopt a reading strategy focusing upon accuracy at the expense of speed. However, little gain may be expected with respect to accuracy, since all children should already be capable of reading the pseudowords correctly, given their knowledge of grapheme-phoneme correspondences. Whatever the explanation for the slow responding of the reading aloud group may be, that the latencies
Figure 4 Exposure duration (in ms), split by orthographical structure and collapsed across presentation frequency

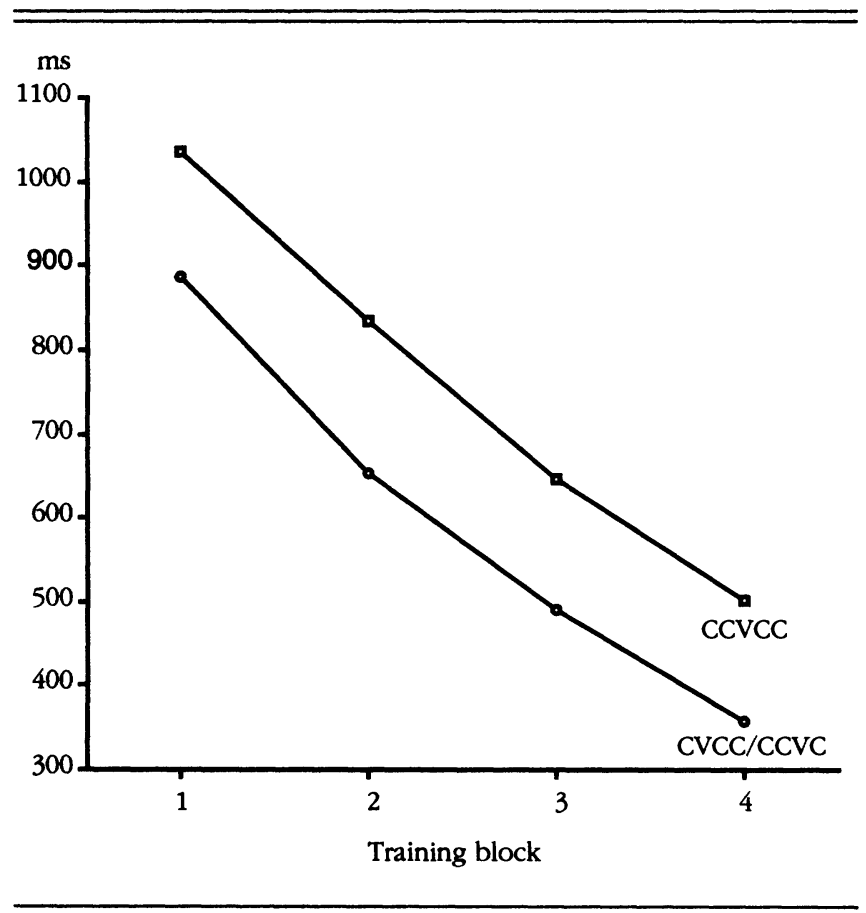

Figure 5 Number of pseudowords correct, split by orthographical structure and collapsed across presentation frequency

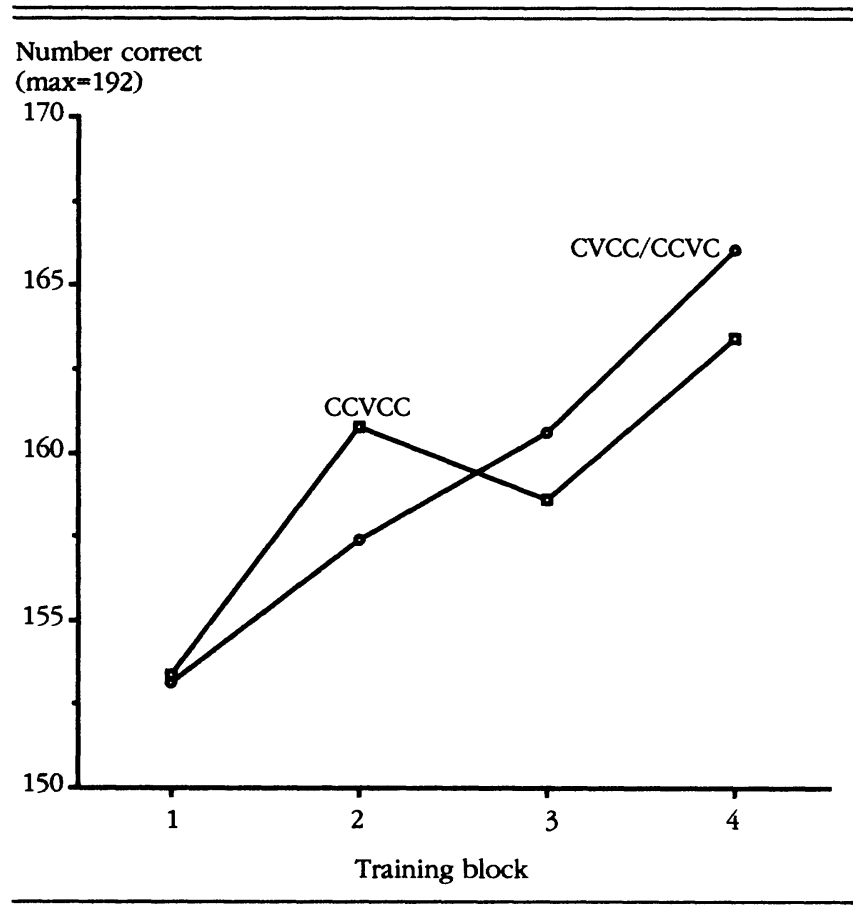


of the no training group were shorter suggests that group differences cannot be simply attributed to a Hawthorne effect, that is, to the experimental groups being aware that they were studied (cf. Ball, 1988). Children of the flashcard group received feedback on "how much time they needed to look at a pseudoword in order to read it correctly." The combination of limited processing time and feedback on fast processing may have induced children to adopt a reading strategy focusing upon speed rather than accuracy.

In the present study, we were unable to replicate the earlier finding (van den Bosch et al., 1990) that training under conditions of limited exposure duration increased the interfering effects of superimposed words and pseudowords on picture-naming speed. In the present study we found pictures with words to be named faster than pictures with consonant strings. This is in conflict with the normal pattern of results obtained in studies using this paradigm (e.g., Schadler \& Thissen, 1981). The reason for this peculiar outcome is yet unclear. This makes the interpretation of the results highly speculative, and we will therefore refrain from discussing these findings in more detail.

The strong version of verbal efficiency theory (Perfetti, 1985) states that improvement in decoding necessarily leads to improvement in comprehension. The present results on the sentence-verification task, however, provide no support for this claim. The overall better results of the flashcard group on the pseudoword reading task did not carry over to text comprehension.

Results with respect to dependent measures during training will be discussed next. Figure 2 shows that training with unlimited presentation time induces slow responding. The two training groups did not differ with respect to pseudoword naming speed at the pretest, but large differences in naming time were already found at the beginning of the training program, indicating that the nature of the task had a large impact on children's processing speed. The results on the word and pseudoword reading posttests suggest that such effects endure beyond the training program, and thus are not the mere manifestations of adaptability to task characteristics.

Both training groups improved their naming speed during training. It is conceivable that this is the result of better articulatory programming or faster execution of a speech program rather than the consequence of improved decoding skills. These questions were taken up in our earlier training study (van den Bosch et al., 1990). In order to test the notion that training leads to faster execution of a speech program, we asked 10-year-old poor readers in each training session to name digits, in addition to words and pseudowords (blockwise presentation). Digit naming latency appeared not to change dur- ing training, suggesting that practice has no effect on the ability to execute automated speech programs. Similarly, the gain in naming speed may have been the product of improved efficiency in transforming the abstract phonological code into a ready-for-use speech code. The plausibility of this articulatory programming hypothesis was addressed by van den Bosch (1991; Experiment 4). He compared relatively good and poor beginning readers on articulatory programming speed by experimentally separating pseudoword naming latency into a decoding component, an articulatory programming component, and a response execution component. The contribution of each component to pseudoword naming latency was estimated. No difference between good and poor readers was found with respect to articulatory programming speed, making it unlikely that this component accounts for the observed progress in naming speed. For these reasons we reject the alternative explanations and regard the progress in naming speed as the product of improved decoding skill.

The results show an effect of pseudoword repetition on the posttest as well as during training. This suggests that poor readers actually learn from prior experience with a word. This is important, since poor readers are less likely than good readers to acquire word specific information when decoding a word, even if their attempt is successful (Adams, 1990, pp. 112-113). Because decoding requires much cognitive effort and is executed very slowly, poor readers often fail to generate full and detailed descriptions of a word's phonological and orthographical attributes and store these as 'amalgamated' representations in long term memory (Ehri, 1980). It is important to note that subjects were not told that some pseudowords were presented more than once during training. The interval between two successive presentations of a pseudoword was one week at minimum (every second session for eight presentations during training). The fact that some pseudowords were repeated should be hard to detect for naive subjects. The conclusion can be drawn that poor readers of this age and reading level can acquire information of a specific pseudoword, store it in long-term memory, and use it to their benefit in subsequent readings of that pseudoword. Whether prior presentations facilitated processes of stimulus identification through the storage of orthographical and phonological information in the lexicon (Ehri, 1980), or processes of response production through the storage of the pseudoword's articulatory program (Balota \& Chumbley, 1985), is an issue that cannot be settled by the present data.

A most interesting outcome is the parallel improvement of words of different length over training. Poor readers were trained in reading monosyllabic pseudo- 
words of different length (either four or five graphemes). Overall naming latency was affected by length. The progress in naming speed, however, was not related to the number of graphemes. The improvement in naming speed for short and for long pseudowords was the same. These findings are in agreement with earlier studies (van Bon, van Kessel, \& Kortenhorst, 1987; van den Bosch et al., 1990). The course of the exposure duration during training exhibits an equivalent pattern. Children required a longer exposure duration to read a five-grapheme than a four-grapheme pseudoword (approximately $300 \mathrm{~ms}$ longer). Once again, the observed progress across training was independent of number of graphemes, as Figure 4 clearly demonstrates. The finding that subjects took longer to name five-grapheme than four-grapheme pseudowords is in agreement with the grapheme-phoneme correspondence (GPC) theory (Coltheart, 1978), which states that decoding is a grapheme-by-grapheme process. This theory also predicts that the impact of decoding progress on naming time should increase with length. However, this is not what we found. The parallel progress in naming time is in conflict with the GPC theory. One way to explain the results is to postulate that children used larger decoding units than individual graphemes and phonemes and that the long and the short words in our studies had the same number of these presupposed multigrapheme units. If, at a certain level of decoding, the number of intermediate units would be identical for CVCC/CCVC and CCVCC, and the training effect is brought about at that level, the model could account for the parallel progress in naming speed. A recent model of decoding that is theoretically consistent with the current finding is the onset-rime model by Treiman (Treiman \& Chafetz, 1987; Treiman \&

Zukowski, 1988; Wise, Olson, \& Treiman, 1990). Further experimental research is required to determine whether this model (or any other multigrapheme decoding model) does indeed account for the length-independent progress.

\section{Conclusions, implications, and recommendations}

The conclusion is warranted that poor readers' word identification skills can be improved by practice in phonological decoding through pseudoword reading, provided that training is carried out under conditions of limited exposure duration.

Training without time pressure seems to have negative rather than positive effects. This finding may have consequences for remedial practice because reading problems are most commonly attacked by tasks that resemble the reading aloud condition of the present study. The present results suggest that this training approach is unproductive because it does not stimulate children to develop faster decoding procedures. Poor readers are often capable of decoding short and simple pseudowords accurately, indicating that they do not lack the necessary grapheme-phoneme knowledge. Their problem is their failure to apply this knowledge efficiently and rapidly. The treatment should therefore consist of tasks that elicit more efficient decoding strategies. The present study suggests that limiting the exposure duration during training can be an effective condition to achieve that goal.

Varying the exposure duration as a function of accuracy proved to be an effective technique and is easy to implement in a computer program. However, simply reading aloud the presented pseudoword may be less appropriate for use in remedial practice. A naming response cannot be evaluated by a computer because spoken word recognition is not yet possible with the technology of today. Assuming that the positive effects of training are not dependent on the type of response, other response modalities may be used in remedial practice. A possible solution would be to remodel the naming task into a lexical decision procedure. Besides pseudowords, the practice materials should also include words. The response in such a task would be very simple, just pressing one of two buttons: a yes button if the letter string forms a word, and a no button if it does not.

The present study showed that training in pseudoword decoding is more effective under conditions of limited exposure duration than without time pressure. The efficacy of this type of training, however, should not be overestimated. Positive effects were fairly small and were observed in training-related tasks only. An important finding is that the training brought about progress in reading words and pseudowords that were not actually practiced. Thus, in contrast to the results of many other word training programs that failed to achieve transfer to untrained material (Fiedorowicz, 1986; Fleisher et al., 1979; Reitsma, 1988b; van Daal et al., 1986), the progress in reading speed is not the result of increased familiarity with a limited set, but applies to all new words and pseudowords. Accordingly, an improvement in decoding is important because it underlies an overall progress in reading ability. In that respect, the results of the present study are a significant contribution to the development of effective training procedures.

\section{REFERENCES}

ADAMS, M.J. (1990). Beginning to read: Thinking and learning about print. Cambridge, MA: MIT Press.

BACKMAN, J., BRUCK, M., HEBERT, M., \& SEIDENBERG, M.S. (1984). Acquisition and use of spelling-sound correspondences in reading. Journal of Experimental Child Psychology, 38, 114-133.

BAKKER, J.J.M. (1972). Constant en variabel [Constant and variable]. Unpublished doctoral dissertation, University of Amsterdam, Amsterdam, The Netherlands. 
BALL, S. (1988). Unintended effects in educational research. In J. Keeves (Ed.), Educational research, methodology and measurement: An international handbook (pp. 490-493). Oxford: Pergamon Press.

BALOTA, D.A., \& CHUMBLEY, J.I. (1985). The locus of word frequency effects in the pronunciation task: Lexical access and/or production? Journal of Memory and Language, 24, 89-106.

BARRON, R.W. (1980). Visual and phonological strategies in reading and spelling. In U. Frith (Ed.), Cognitive processes in spelling (pp. 195-213). London: Academic Press.

$\rightarrow$ BRADLEY, L., \& BRYANT, P.E. (1983). Categorizing sounds and learning to read-A causal connection. Nature, 301, 419-421.

$\rightarrow$ BRIGGS, P., AUSTIN, S., \& UNDERWOOD, G. (1984). The effects of sentence context in good and poor readers: A test of Stanovich's interactive-compensatory model. Reading Research Quarterly, 20, 54-61.

$\rightarrow$ BRUCK, M. (1988). The word recognition and spelling of dyslexic children. Reading Research Quarterly, 23, 51-69.

COHEN, J. (1988). Statistical power analysis for the behavioral sciences (2nd ed.). Hillsdale, NJ: Erlbaum.

COLTHEART, M. (1978). Lexical access in simple reading tasks. In G. Underwood (Ed.), Strategies of information processing (pp. 151216). London: Academic Press.

EHRI, L.C. (1980). The development of orthographic images. In U. Frith (Ed.), Cognitive processes in spelling (pp. 311-338). London: Academic Press.

EHRI, L.C., \& WILCE, L.S. (1983). Development of word identification speed in skilled and less skilled beginning readers. Journal of Educational Psychology, 75, 3-18.

FIEDOROWICZ, C.A.M. (1986). Training of component reading skills. Annals of Dyslexia, 36, 318-334.

$\rightarrow$ FLEISHER, L.S., JENKINS, J.R., \& PANY, D. (1979). Effects on poor readers' comprehension of training in rapid decoding. Reading Research Quarterly, 15, 30-48.

HAND, D.J., \& TAYLOR, C.C. (1987). Multivariate analysis of variance and repeated measures: A practical approach for behavioural scientists. London: Chapman and Hall.

HENDERSON, L. (1985). Issues in the modelling of pronunciation assembly in normal reading. In K.E. Patterson, J.C. Marshall, \& M. Coltheart (Eds.), Surface dyslexia: Neuropsychological and cognitive studies of phonological reading (pp. 459-508). Hillsdale, NJ: Erlbaum.

HOGABOAM, T.W., \& PERFETTI, C.A. (1978). Reading skill and the role of verbal experience in decoding. Journal of Educational Psychology, 70(5), 717-729.

LABERGE, D., \& SAMUELS, S.J. (1974). Toward a theory of automatic information processing in reading. Cognitive Psychology, 6, 293323.

LOVETT, M.W., WARREN-CHAPLIN, P.M., RANSBY, M.J., \& BORDEN, S.L. (1990). Training the word recognition skills of reading disabled children: Treatment and transfer effects. Journal of Educational Psychology, 82(4), 769-780.

MANN, V.A., LIBERMAN, I.Y., \& SHANKWEILER, D. (1980). Children's memory for sentences and word strings in relation to reading experience. Cognition, 24, 65-92.

PERFETTI, C.A. (1985). Reading ability. New York: Oxford University Press.

PERFETTI, C.A., BECK, I., BELL, L.C., \& HUGHES, C. (1987). Phonemic knowledge and learning to read are reciprocal: A longitudinal study of first grade children. Merrill-Palmer Quarterly, 33(3), 283-319.

PERFETTI, C.A., \& ROTH, S. (1981). Some of the interactive processes in reading and their role in reading skill. In A. Lesgold \& C.A.
Perfetti (Eds.), Interactive processes in reading (pp. 269-297). Hillsdale, NJ: Erlbaum.

PRING, L., \& SNOWLING, M. (1986). Developmental changes in word recognition: An information-processing account. The Quarterly Journal of Experimental Psychology, 38(A), 395-418.

REITSMA, P. (1983). Word-specific knowledge in beginning reading. Journal of Research in Reading, $\sigma(1), 41-56$.

$\rightarrow$ REITSMA, P. (1988a). Reading practice for beginners: Effects of guided reading, reading-while-listening, and independent reading with computer-based speech feedback. Reading Research Quarterly, 23, 219-235.

REITSMA, P. (1988b). Tussen letter en woord: Het effect van oefening met wisselrijen [Between the letter and the word: Effects of practice with structure lists]. Pedagogische Studieën, 65(9), 344-357.

$\rightarrow$ ROTH, S.F., \& BECK, I.L. (1987). Theoretical and instructional implications of the assessment of two microcomputer word recognition programs. Reading Research Quarterly, 22, 197-218.

SCHADLER, M., \& THISSEN, D.M. (1981). The development of automatic word recognition and reading skill. Memory and Cognition, 9(2), 132-141.

STANNERS, R.F., \& FORBACH, G.B. (1973). Analysis of letter strings in word recognition. Journal of Experimental Psychology: General, 98, 31-35.

$\rightarrow$ STANOVICH, K.E. (1980). Toward an interactive compensatory model of individual differences in the development of reading fluency. Reading Research Quarterly, 1, 33-71.

$\rightarrow$ STANOVICH, K.E. (1986). Matthew effects in reading: Some consequences of individual differences in the acquisition of literacy. Reading Research Quarterly, 21, 360-406.

STAPHORSIUS, G., KROM, R.S.H., \& DE GEUS, K. (1989). Frequenties van woordvormen en letterposities in jeugdlectuur [Frequencies of words and letter positions in books for children]. Arnhem, The Netherlands: Cito.

TREIMAN, R., \& CHAFETZ, J. (1987). Are there onset- and rime-like units in printed words? In M. Coltheart (Ed.), Attention and performance (Vol. 12, pp. 281-298). Hillsdale, NJ: Erlbaum.

TREIMAN, R., \& ZUKOWSKI, A. (1988). Units in reading and spelling. Journal of Memory and Language, 27, 466-477.

VAN BON, W.H.J. (in press). Remediation of reading problems: Effects of training at word and subword levels. In E.M.H. Assink (Ed.), Literacy acquisition and social context. Hemel Hempstead, Herts., UK: Harvester Wheatsheaf.

VAN BON, W.H.J., VAN KESSEL, A.E.G., \& KORTENHORST, E.P.M. (1987). Beïnvloeding van woordherkenningssnelheid door middel van flash cards [Affecting word identification speed by flash cards]. In J. Hamers \& A. van der Leij (Eds.), Dyslexie (pp. 87-94). Lisse, The Netherlands: Swets \& Zeitlinger.

VAN DAAL, V.H.P., BAKKER, N.C.M., REITSMA, P., \& VAN DER LEIJ, D.A.V. (1986). Woordfrequentie, repetitie en ernstige leesproblemen [Word frequency, repetition, and severe reading problems]. In P. Reitsma, A.G. Bus, \& W.H.J. van Bon (Eds.), Leren lezen en spellen; Ontwikkeling en problemen [Learning to read and spell: Development and problems], pp. 40-45. Lisse, The Netherlands: Swets \& Zeitlinger.

VAN DEN BOSCH, K. (1991). Poor readers' decoding skills: Effects of training, task, and word characteristics. Unpublished doctoral dissertation, University of Nijmegen, Nijmegen, The Netherlands.

VAN DEN BOSCH, K., VAN BON, W.H.J., \& SCHREUDER, R. (1990). Flash cards; een vergelijking van toepassingsprocedures [Flash cards: A comparison of practice procedures]. Tijdschrift voor Orthopedagogiek, 24, 233-244.

VELLUTINO, F.R., \& SCANLON, D.M. (1987). Linguistic coding and reading ability. In S. Rosenberg (Ed.), Advances in applied psy- 
cholinguistics (Vol. 2, pp. 1-6g). Cambridge: Cambridge University Press.

WAGNER, R.K., \& TORGESEN, J.K. (1987). The nature of phonological processing and its causal role in the acquisition of reading skills. Psychological Bulletin, 101(2), 192-212.

$\rightarrow$ WEST, R.E., \& STANOVICH, K.E. (1982). Source of inhibition in experiments on the effects of sentence context on word recognition. Journal of Experimental Psychology: Learning, Memory, and Cognition, 8, 385-399.

WISE, B.W., OLSON, R.K., \& TREIMAN, R. (1990). Subsyllabic units in computerized reading instruction: Onset rime vs postvowel segmentation. Journal of Experimental Child Psychology, 49, 1-19.

Received June 23, 1992

Final revision received April 14, 1994

\section{APPENDIXES}

\section{APPENDIX A \\ Examples of pseudowords used as practice materials}

CVCC pseudowords

baaks, dets, faamp, gaalp, heump, juusp, keemp, lirs, naats, peufs

CCVC pseudowords

bleip, dral, fleik, gruil, krien, preul, sloef, twip, vruus, zwuuf

CCVCC pseudowords

blarp, dremp, fleuts, glijmp, klirf, pliems, spoers, treps, vlirp, zwomp
Accepted June 21, 1994

\section{AUTHOR NOTES}

This study was part of the dissertation research project of the first author, who is now working at the TNO Human Factors Research Institute at Soesterberg, The Netherlands.

The authors express their gratitude to Jacqueline Klerkx and Monique van Zon for collecting the data, and to the following schools for their cooperation and assistance in the conduct of this study: Carolusschool in Nijmegen and de Schans in Tilburg.

For further information contact Wim H.J. van Bon at the Department of Special Education, University of Nijmegen, PO Box 9103, 6500 HD Nijmegen, The Netherlands.

\section{APPENDIX B Examples of high-frequency words used in pre- and posttests}

\section{CVCC words}

berg, dorp, fiets, hals, kaart, melk, niets, punt, rots, soort, tent

CCVC words

blik, draak, fles, gras, klas, plein, sloot, trein, vlees, zwaar

CCVCC words

brons, dwars, flink, grens, klant, plant, sport, trots, zwart

\section{APPENDIX C Examples of sentences used for the sentence verification task}

De broek is vies 'The pants are dirty'

Een kat is een plant 'A cat is a plant'

De kraan lekt 'The tap is leaking'

De mat ligt voor de deur 'The mat is in front of the door'

Een kers is vlees 'A cherry is meat'

Het oor ruikt soep 'The ear smells soup'

Het vuur is warm 'The fire is warm'

Jos koopt een fles wijn 'Josh buys a bottle of wine'

Melk is klein 'Milk is small'

Vijf is meer dan zes 'Five is more than six' 